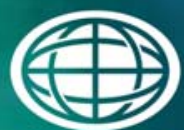

Savannah River

National Laboratory

OPERATED BY SAVANNAH RIVER NUCLEAR SOLUTIONS

\title{
Sample Results from the Interim Salt Disposition Program Macrobatch 7 Tank 21H Qualification Samples
}

T. B. Peters

A. L. Washington, II

August 2013

SRNL-STI-2013-00437

Revision 0 


\section{DISCLAIMER}

This work was prepared under an agreement with and funded by the U.S. Government. Neither the U.S. Government or its employees, nor any of its contractors, subcontractors or their employees, makes any express or implied:

1. warranty or assumes any legal liability for the accuracy, completeness, or for the use or results of such use of any information, product, or process disclosed; or

2. representation that such use or results of such use would not infringe privately owned rights; or

3. endorsement or recommendation of any specifically identified commercial product, process, or service.

Any views and opinions of authors expressed in this work do not necessarily state or reflect those of the United States Government, or its contractors, or subcontractors.

\section{Printed in the United States of America}

Prepared for

U.S. Department of Energy 


\section{Sample Results from the Interim Salt Disposition Program Macrobatch 7 Tank 21H Qualification Samples}

T. B. Peters

A. L. Washington, II

August 2013

Prepared for the U.S. Department of Energy under contract number DE-AC09-08SR22470.

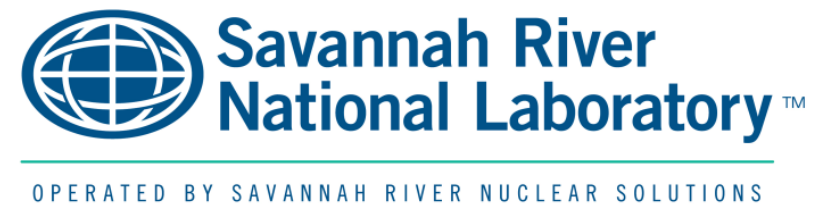




\section{REVIEWS AND APPROVALS}

\section{AUTHORS:}

T. B. Peters, Author, SRNL/ACP

Date

A. L. Washington II, Co-author, SRNL/ACP

Date

TECHNICAL REVIEW: (Reviewed per E7 2.60)

C. A. Nash, Technical Reviewer, SRNL/ACP

Date

\section{APPROVAL:}

F. M. Pennebaker, SRNL/ACP, Manager

Date

S. L. Marra, SRNL/E\&CPT Research Programs, Manager

Date

K. H. Subramanian, Manager, SRR Flowsheet Integration and Technology Date

E. J. Freed, Manager, DWPF Facility Engineering

Date 


\section{EXECUTIVE SUMMARY}

Savannah River National Laboratory (SRNL) analyzed samples from Tank 21H in support of qualification of Macrobatch (Salt Batch) 7 for the Interim Salt Disposition Program (ISDP). An ARP and several ESS tests were also performed. This document reports characterization data on the samples of Tank $21 \mathrm{H}$ as well as simulated performance of ARP/MCU. No issues with the projected Salt Batch 7 strategy are identified, other than the presence of visible quantities of dark colored solids.

A demonstration of the monosodium titanate $(0.2 \mathrm{~g} / \mathrm{L})$ removal of strontium and actinides provided acceptable 4 hour average decontamination factors for Pu and $\mathrm{Sr}$ of 3.22 and 18.4, respectively. The Four ESS tests also showed acceptable behavior with distribution ratios $\left(\mathrm{D}_{(\mathrm{Cs})}\right)$ values of 15.96, 57.1, 58.6, and 65.6 for the MCU, cold blend, hot blend, and Next Generation Solvent (NGS), respectively. The predicted value for the MCU solvent was 13.2. Currently, there are no models that would allow a prediction of extraction behavior for the other three solvents. SRNL recommends that a model for predicting extraction behavior for cesium removal for the blended solvent and NGS be developed.

While no outstanding issues were noted, the presence of solids in the samples should be investigated in future work. It is possible that the solids may represent a potential reservoir of material (such as potassium) that could have an impact on MCU performance if they were to dissolve back into the feed solution.

This salt batch is intended to be the first batch to be processed through MCU entirely using the new NGS-MCU solvent. 


\section{LIST OF ABBREVIATIONS}

$\begin{array}{ll}\text { AA } & \text { Atomic Absoption } \\ \text { AD } & \text { Analytical Development } \\ \text { AMP } & \text { ammonium molybdophosphate } \\ \text { ARP } & \text { Actinide Removal Project } \\ \text { CVHg } & \text { Cold Vapor Mercury } \\ \text { D }_{\text {(Cs) }} & \text { distribution ratio for cesium } \\ \text { DF } & \text { decontamination factor } \\ \text { ESS } & \text { extraction, scrub, strip } \\ \text { IC } & \text { Ion Chromatography } \\ \text { ICPES } & \text { Inductively Coupled Plasma Emission Spectroscopy } \\ \text { ICPMS } & \text { Inductively Coupled Plasma Mass Spectroscopy } \\ \text { ISDP } & \text { Interim Salt Disposition Program } \\ \text { MCU } & \text { Modular CSSX Unit } \\ \text { MST } & \text { monosodium titanate } \\ \text { NGS } & \text { Next Generation Solvent } \\ \text { PuTTa } & \text { plutonium thenoyl trifluoroacetone scintillation } \\ \text { RSD } & \text { relative standard deviation (percent) } \\ \text { SRNL } & \text { Savannah River National Laboratory } \\ \text { SRR } & \text { Savannah River Remediation } \\ \text { TIC-TOC } & \text { Total Inorganic Carbon-Total Organic Carbon } \\ \text { TTQAP } & \text { Task Technical and Quality Assurance Plan } \\ \text { TTR } & \text { Technical Task Request } \\ \text { WAC } & \text { Waste Acceptance Criteria } \\ & \end{array}$




\subsection{Introduction}

This report covers the Tank $21 \mathrm{H}$ qualification sample results for Macrobatch (Salt Batch) 7 of the Interim Salt Disposition Program (ISDP). A previous document covers initial characterization which includes results for a number of non-radiological analytes. ${ }^{1}$ This work was specified by Technical Task Request ${ }^{2}$ and by Task Technical and Quality Assurance Plan (TTQAP). ${ }^{3}$

Details for the work are contained in controlled laboratory notebooks. ${ }^{4}$

\subsection{Experimental Procedure}

Three Tank 21H samples (i.e., $80 \mathrm{~mL}$ dip sample bottles HTF-21-13-79 and HTF-21-1380, and a 2 L sample HTF-21-13-81) were pulled on May 16 and arrived at SRNL on May 16, 2013. The samples each contained visible quantities of fine dark colored solids, which is not typical. $10 \mathrm{~mL}$ well-mixed samples from each of the three sample bottles were then removed for archival purposes. A well-mixed portion of material from HTF21-13-81 was placed in a $100 \mathrm{~mL}$ graduated cylinder. Over a period of 29 hours, the contents were allowed to settle and multiple pictures were taken. See Figure 1.

\section{Figure 1. Pictures of Settling Tank 21H Sample}

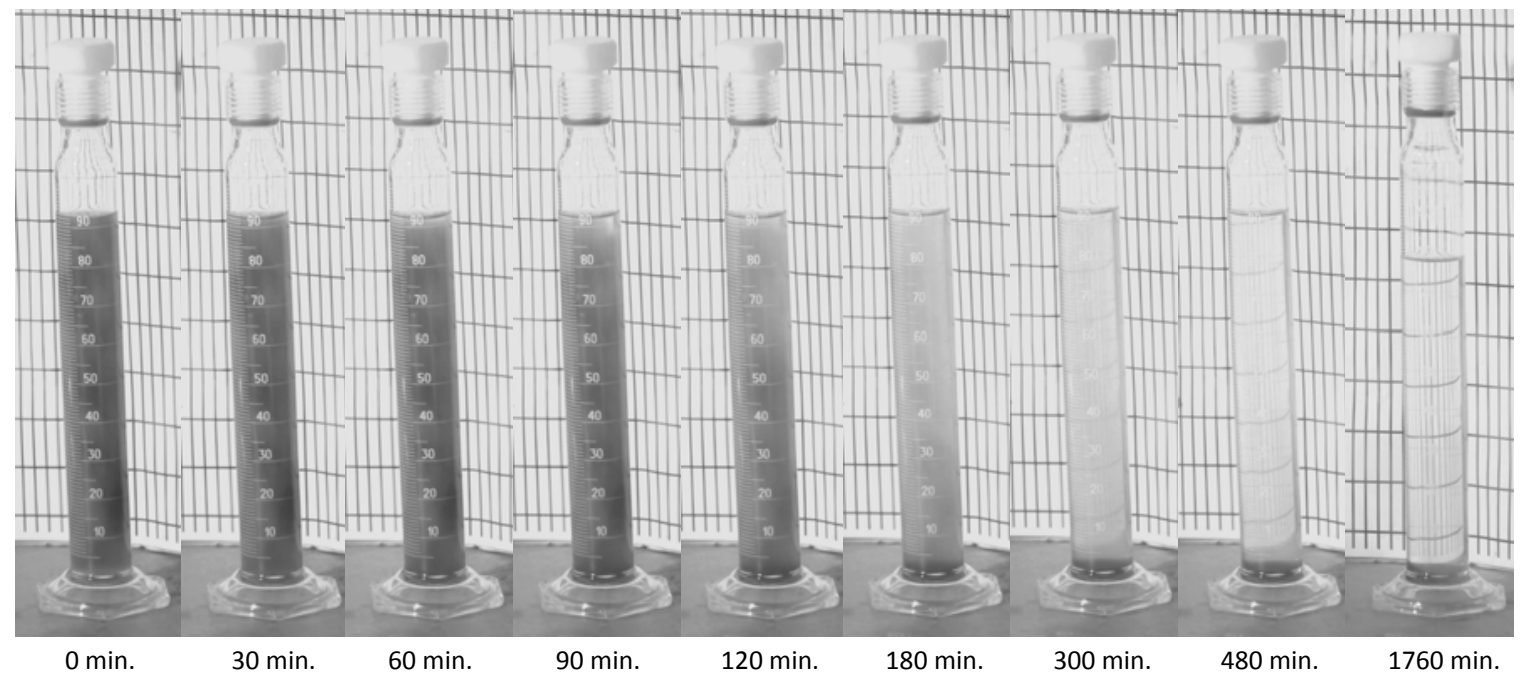

Within 2 hours, there was visible stratification in the sample. After 8 hours, the sample was mostly settled, and by 29 hours, the sample had visibly clarified. Please note that the missing supernate in the last picture $(t=1760)$ is due to a sample having been removed for analytical purposes. ${ }^{1}$ The length of settling was designed to conservatively bound the time the feed tank would settle, accounting for the different settling heights. ${ }^{5}$ 
The density of filtered samples (using a $0.45 \mu \mathrm{m}$ syringe filter) from each sample were measured and tabulated. The samples of the clarified material were also measured for density, without any filtration. The results of the density measurements are listed in Table 1.

With customer concurrence, the contents of the three sample bottles (HTF-21-13-79, 80, 81) were then combined and mixed. After combining, duplicate filtered samples (using a $0.45 \mu \mathrm{m}$ syringe filter) were sent to Analytical Development (AD) for analysis without dilution. For the weight\% solids $\nabla^{\nabla}$ and "total Pu", samples of the clarified material were sent forward for analyses.

\section{$\underline{2.1 \text { MST Sorption Test }}$}

The Tank $21 \mathrm{H}$ composite material had visible quantities of dark colored solids. These solids were allowed to settle for 29 hours before the supernate was removed for use.

For the MST Sorption Test, approximately $475 \mathrm{~mL}$ of the ISDP7 Tank 21H material was obtained for processing. The composite salt solution was previously measured with a density of $1.272 \mathrm{~g} / \mathrm{mL}$ at $\left(25^{\circ} \mathrm{C}\right) .200 \mathrm{~mL}$ each (totaling $400 \mathrm{~mL}$ ) of the salt solution was placed into the first and second experiment bottles, while the remainder ( $75 \mathrm{~mL})$ was placed into the control bottle. Two experiment bottles were used in order to provide enough solution for the later ESS tests.

All three bottles had magnetic stir bars added to provide sufficient mixing for batch contact tests. The target concentration for MST was $0.2 \mathrm{~g} / \mathrm{L}$. Personnel added $0.253 \mathrm{~g}$ of MST solids in a 15.8 wt \% solution from Blue Grass Chemical Specialties MST-2723 to each experiment bottle. This material was an archived batch that has been utilized on all recent salt batches by SRNL. The time was recorded and designated as time 0 . Throughout the course of the MST test, agitation and temperature control $\left(25 \pm 3^{\circ} \mathrm{C}\right)$ were provided.

During the experiment, samples were collected from each of the three bottles

at 0,4 and 8 hours. For the sample at 0 hours, sampling occurred immediately prior to MST addition solely from the control bottle. For the sample at 4 and 8 hours, sampling occurred immediately at the 4 or 8 hour mark preventing additional MST sorption. Personnel filtered the samples using $0.45 \mu \mathrm{m}$ Versapor тм syringe filters, removed the samples from the cells for analysis, and analyzed for plutonium (PuTTA), ${ }^{90} \mathrm{Sr}$ (beta scintillation), and ${ }^{238} \mathrm{U}$ (ICPMS). Samples were sent to AD with moderate dilution, and those dilutions are accounted for in the presented data. This test uses the same protocol as used in the previous Macrobatch testing. ${ }^{6}$

\footnotetext{
${ }^{\nabla}$ The wt\% solids used M\&TE balances in their sample preparation. Other analyses used M\&TE where appropriate.
} 


\subsection{ESS Demonstration}

For the ESS Demonstrations, filtrate from the MST Sorption Demonstration was used. Using this material, the researchers performed four ESS tests. All of the tests used the same general protocol as used in the previous Macrobatch testing. ${ }^{6}$ The first test used a nominal starting volume of $90 \mathrm{~mL}$ of aqueous feed and $30 \mathrm{~mL}$ of fresh, unused MCU solvent for extraction." In the second test, the NGS solvent was used." In the third ESS test, the NGS-MCU solvent blend ${ }^{\vee}$ was used, where the MCU solvent was radiologically clean (unused, "Cold blend"). In the fourth ESS test, the NGS-MCU solvent blend ("Hot blend") was used, where the MCU solvent blend was prepared from previously processed solvent from MCU. The second, third and fourth tests all used $80 \mathrm{~mL}$ of aqueous feed and $20 \mathrm{~mL}$ of solvent for extraction. For the first test, the scrub and strip solutions were $0.05 \mathrm{M}$ and $0.001 \mathrm{M}$ nitric acid, respectively. For the other three tests, the scrub and strip solutions were $0.025 \mathrm{M} \mathrm{NaOH}$ and $0.01 \mathrm{M}$ boric acid, respectively. In order to prevent cross-contamination of the different scrub and strip solutions, the first test was performed in a separate physical location than the other three tests. Confirmation by $\mathrm{pH}$ strip was also performed.

\subsection{Quality Assurance}

Requirements for performing reviews of technical reports and the extent of review are established in manual E7 2.60. SRNL documents the extent and type of review using the SRNL Technical Report Design Checklist contained in WSRC-IM-2002-00011, Rev. 2.

\subsection{Results and Discussion}

The density of filtered samples (using a $0.45 \mu \mathrm{m}$ syringe filter) from each sample were measured and tabulated. The samples of the clarified material were also measured for density, without any filtration. The results of the density measurements are listed in Table 1.

\footnotetext{
- MCU solvent is composed of four components; 0.007 M BOBCalixC6 (Calix[4]arene-bis(t-octylbenzo-crown-6), 0.75M Cs-7SB Modifier (1-(2,2,3,3-tetrafluoropropoxy)-3-(4-sec-butylphenoxy)-2-propanol), 0.003 trioctylamine (TOA), and the balance Isopar ${ }^{\mathrm{TM}} \mathrm{L}$. This particular batch was from a prepared lot S2-D1-YESBOB-T-WI.

- NGS solvent is composed of four components; 0.05 M MaxCalix (1,3-alt-25,27-bis(3,7-dimethyloctyl-1oxy)calix[4]arene-benzocrown-6), 0.5 M Cs-7SB Modifier (1-(2,2,3,3-tetrafluoropropoxy)-3-(4-sec-butylphenoxy)-2propanol), 0.003 M TiDG (N,N',N”-tris (3,7-dimethyloctyl) guanidine) and the balance Isopar TM L.

" The NGS-MCU blend (either hot or cold) is a 50/50 volume \% blend of MCU solvent and a prepared mixture of compounds, that once mixed give a nominal composition as follows: $0.0035 \mathrm{M}$ BOBCalixC6, 0.5M Cs-7SB Modifier , 0.0015 M (TOA), 0.003 M TiDG, 0.0465 M MaxCalix, and the balance Isopar ${ }^{\mathrm{TM}} \mathrm{L}$. In the case of the cold blend solvent, the MCU solvent was from batch S2-D1-YESBOB-T-WI. In the case of the hot blend solvent, the MCU solvent was from a composite of samples MCU-13-143/144/145/146/147/148.
} 
Table 1. Sample Density Measurements $\left(25^{\circ} \mathrm{C}\right)$

\begin{tabular}{|c|c|}
\hline Sample & Measured Density (g/mL) \\
\hline HTF-21-13-79 (settled) & 1.293 \\
\hline HTF-21-13-80 (settled) & 1.260 \\
\hline HTF-21-13-81 (settled) & 1.262 \\
\hline HTF-21-13-79 (filtered) & 1.248 \\
\hline HTF-21-13-80 (filtered) & 1.229 \\
\hline HTF-21-13-81 (filtered) & 1.256 \\
\hline Average, settled (\%RSD) & $1.272(1.45 \%)$ \\
\hline Average, filtered (\%RSD) & $1.244(1.11 \%)$ \\
\hline
\end{tabular}

The analytical uncertainty is typically $<1 \%$ for density measurements. Values in parentheses are the relative standard deviation (RSD). ${ }^{\wp}$

The slight differences in the settled and filtered values are not statistically significant. In a previous document, ${ }^{1}$ density, Inductively Coupled Plasma Emission Spectroscopy (ICPES), Ion Chromatography (IC) and Free Hydroxide results were reported for the Tank 21H composite. These results are also reported here for completeness (Table 2). The analytical uncertainty for the IC results is $10 \%$. The analytical uncertainty for the TIC/TOC results is $10 \%$. The analytical uncertainty for the Free Hydroxide result is $10 \%$. The values in the parentheses are the \%RSD. The TIC and TOC results are in terms of $\mathrm{mg} / \mathrm{L}$ of carbon. If we assume that the entire TIC result is carbonate, this translates to a carbonate concentration of $0.299 \mathrm{M}$. The free hydroxide converts to a $\mathrm{pH}$ of 14 . The nickel ( $\mathrm{Ni}$ ) result converted into a concentration of $\mathrm{Ni}(\mathrm{OH})_{2}$ is $<3.27 \mathrm{mg} / \mathrm{L}$.

\footnotetext{
$\wp$ RSD is defined as the standard deviation of the array, divided by the average of the array, expressed in \% terms.
} 
Table 2. Previous Results

\begin{tabular}{|c|c|c|c|}
\hline Analyte & Result (mg/L) & Analyte & Result (mg/L) \\
\hline $\mathrm{Ag}$ & $<1.12$ & $\mathrm{Sb}$ & $<34.5$ \\
\hline $\mathrm{Al}$ & 3320 (0.21\%) & $\mathrm{Si}$ & $74.2(0.76 \%)$ \\
\hline B & $56.6(0.13 \%)$ & Sn & $<11.8$ \\
\hline $\mathrm{Ba}$ & $<0.62$ & $\mathrm{Sr}$ & $<0.05$ \\
\hline $\mathrm{Be}$ & $<0.12$ & Th & $<5.12$ \\
\hline $\mathrm{Ca}$ & $1.18(0.60 \%)$ & $\mathrm{Ti}$ & $<0.58$ \\
\hline $\mathrm{Cd}$ & $<0.84$ & $\mathrm{U}$ & $<28.2$ \\
\hline $\mathrm{Ce}$ & $<6.45$ & V & $<0.63$ \\
\hline $\mathrm{Cr}$ & $38.0(0.19 \%)$ & $\mathrm{Zn}$ & $4.90(0.29 \%)$ \\
\hline $\mathrm{Cu}$ & $<0.98$ & $\mathrm{Zr}$ & $<0.49$ \\
\hline $\mathrm{Fe}$ & $1.51(5.62 \%)$ & $\mathrm{F}^{-}$ & $<100$ \\
\hline Gd & $<1.38$ & $\mathrm{Cl}^{-}$ & $264(0.81 \%)$ \\
\hline $\mathrm{K}$ & $288(1.47 \%)$ & $\mathrm{Br}^{-}$ & $<1000$ \\
\hline $\mathrm{La}$ & $<1.26$ & Formate & 649 (0.55\%) \\
\hline $\mathrm{Li}$ & $21.9(0.00 \%)$ & Nitrite & 33000 (0.86\%) \\
\hline $\mathrm{Mg}$ & 0.183 (5.81\%) & Nitrate & $148,000(1.44 \%)$ \\
\hline $\mathrm{Mn}$ & $<0.16$ & Phosphate & $556(0.13 \%)$ \\
\hline Mo & $<5.99$ & Sulfate & $9080(0.23 \%)$ \\
\hline $\mathrm{Na}$ & $137,000(0.52 \%)$ & Oxalate & $392(0.54 \%)$ \\
\hline $\mathrm{Ni}$ & $<2.07$ & TIC & 3590 (0.59\%) \\
\hline $\mathrm{P}$ & $212(1.00 \%)$ & TOC & $327(0.43 \%)$ \\
\hline $\mathrm{Pb}$ & $<8.18$ & Free Hydroxide & $1.93(1.10 \%) \mathrm{M}$ \\
\hline $\mathrm{S}$ & 3140 (1.58\%) & & \\
\hline
\end{tabular}

Values in parentheses are the RSD.

The bulk chemical characteristics of this batch are roughly similar to that of Salt batch 6 .

\subsection{Tank 21H Qualification Analyses}

The tank samples were analyzed by Analytical Development (AD) by the listed nonradiological methods (Table 3) and radiological (Table 4) methods. Analyses were performed in duplicate and reported in Tables 5 and 6, respectively. Averages of the individual results, with the percent relative standard deviation (RSD) in parentheses, are reported. 
Table 3. Non-Radiological Analyses

\begin{tabular}{|c|c|}
\hline Method & Analyte \\
\hline IC Cations & $\mathrm{NH}_{4}{ }^{+}$ \\
\hline IC Anions & $\begin{array}{c}\mathrm{F}, \mathrm{Cl}, \mathrm{Br} \text {, formate, nitrite, nitrate, } \\
\text { sulfate, phosphate, oxalate }\end{array}$ \\
\hline TIC & total inorganic carbon \\
\hline TOC & total organic carbon \\
\hline AA-As & $\mathrm{As}$ \\
\hline AA-Se & $\mathrm{Se}$ \\
\hline CV-Hg & $\mathrm{Hg}$ \\
\hline HPLC & tetraphenylborate, phenol \\
\hline SVOA & tributylphosphate \\
\hline VOA & isopropanol, butanol, isobutanol \\
\hline
\end{tabular}

Table 4. Radiological Analyses

\begin{tabular}{|c|c|}
\hline Method & Analyte \\
\hline Tritium & ${ }^{3} \mathrm{H}$ \\
\hline${ }^{14} \mathrm{C}$ & ${ }^{14} \mathrm{C}$ \\
\hline gamma scan, Cs-removed & $\begin{array}{c}{ }^{60} \mathrm{Co},{ }^{94} \mathrm{Nb},{ }^{106} \mathrm{Ru},{ }^{125} \mathrm{Sb},{ }^{126} \mathrm{Sn}, \\
{ }^{144} \mathrm{Ce},{ }^{154} \mathrm{Eu},{ }^{155} \mathrm{Eu},{ }^{241} \mathrm{Am},{ }^{226} \mathrm{Ra}\end{array}$ \\
\hline${ }^{90} \mathrm{Sr}$ & ${ }^{90} \mathrm{Sr}$ \\
\hline${ }^{129} \mathrm{I}$ & ${ }^{129} \mathrm{I}$ \\
\hline gamma scan & ${ }^{134} \mathrm{Cs},{ }^{137} \mathrm{Cs}$ \\
\hline${ }^{232} \mathrm{U}$ & ${ }^{232} \mathrm{U}$ \\
\hline $\begin{array}{l}{ }^{238-241} \mathrm{Pu} \text { (filtered and unfiltered) (Plutonium } \\
\text { thenoyl trifluoroacetone scintillation) }\end{array}$ & ${ }^{238} \mathrm{Pu},{ }^{239 / 40} \mathrm{Pu},{ }^{241} \mathrm{Pu}$ \\
\hline $\mathrm{Am} / \mathrm{Cm}$ & ${ }^{241} \mathrm{Am},{ }^{243} \mathrm{Am},{ }^{244} \mathrm{Cm},{ }^{245} \mathrm{Cm}$ \\
\hline${ }^{59 / 63} \mathrm{Ni}$ & ${ }^{59 / 63} \mathrm{Ni}$ \\
\hline${ }^{99} \mathrm{Tc}$ & ${ }^{99} \mathrm{Tc}$ \\
\hline${ }^{147} \mathrm{Pr} /{ }^{151} \mathrm{Sm}$ & ${ }^{147} \mathrm{Pr} /{ }^{151} \mathrm{Sm}$ \\
\hline $\begin{array}{l}\text { ICPMS (Inductively Coupled Plasma Mass } \\
\text { Spectroscopy) }\end{array}$ & $\begin{array}{l}\text { isotopes from mass number } 81 \text { to } \\
209 \text { and } 230 \text { to } 252, \text { incl. }{ }^{233} \mathrm{U} \text { and } \\
\text { above, }{ }^{237} \mathrm{~Np},{ }^{230} \mathrm{Th},{ }^{232} \mathrm{Th}\end{array}$ \\
\hline Liquid Scintillation Counting & total alpha, total beta \\
\hline
\end{tabular}

\subsection{Tank 21H Qualification Results (non-radiological analytes)}

The results for the IC-Cations, weight percent insoluble solids, phenol, tetraphenylborate, tributyl phosphate, isopropanol, methanol, isobutanol, butanol, arsenic, mercury, and selenium are listed in Table 5. The analytical uncertainty for all listed analyses is $20 \%$, except for the IC-Cations and wt\% insoluble solids, which are $10 \%$. Shaded results are calculated results. Results shaded in green are calculated results. Values in parentheses are RSD. 
Table 5. Miscellaneous Results (mg/L unless otherwise noted)

\begin{tabular}{|c|c|}
\hline Analyte & Result \\
\hline ammonium & $<100$ \\
\hline wt \% insoluble solids & $0.0147(53.6 \%) \mathrm{wt} \%$ \\
\hline phenol & $<10$ \\
\hline tetraphenylborate & $<10$ \\
\hline tributylphosphate & $<0.25$ \\
\hline isopropanol & $<0.25$ \\
\hline butanol & $<0.25$ \\
\hline isobutanol & $<0.25$ \\
\hline methanol & $<125$ \\
\hline As & $0.181(32.8 \%)$ \\
\hline Hg & $79.0(19.5 \%)$ \\
\hline Se & $0.308(0.00 \%)$ \\
\hline
\end{tabular}

Methanol is a calculated value.

Values in parentheses are the RSD.

SRNL was unable to meet the requested detection limit for ammonium and tetraphenylborate due to the high salt content of the samples.

The oxalate concentration is $392 \mathrm{mg} / \mathrm{L}$, and the formate result is $649 \mathrm{mg} / \mathrm{L}$. The oxalate result is converted to the equivalent carbon result of $173 \mathrm{mg} / \mathrm{L}$. The formate result is converted to the equivalent carbon result of $107 \mathrm{mg} / \mathrm{L}$. Subtracting these results from the TOC result gives a remainder of $47 \mathrm{mg} / \mathrm{L}$ of carbon. If we assume all of this remainder carbon is in the form of methanol, this gives a calculated methanol result of $125 \mathrm{mg} / \mathrm{L}$. This methanol result should be considered an upper bound as no direct analytical method for methanol exists.

\subsection{Tank 21H Qualification Results (radiological analytes)}

The results of the radiological analysis in $\mathrm{pCi} / \mathrm{mL}$ are listed in Table 6 . The analytical uncertainty for ICPMS samples are $20 \%$. Other analytical methods have varying uncertainties, typically 5-10\% and are noted for single sample results.

${ }^{90} \mathrm{Y}$ is calculated as equal to the ${ }^{90} \mathrm{Sr}$ result. ${ }^{106} \mathrm{Rh}$ is calculated as equal to the ${ }^{106} \mathrm{Ru}$ result. The ${ }^{125 \mathrm{~m}} \mathrm{Te}$ is calculated as equal to the ${ }^{125} \mathrm{Sb}$ result. ${ }^{137 \mathrm{~m}} \mathrm{Ba}$ is calculated as $94.7 \%$ of the ${ }^{137} \mathrm{Cs}$ result (as seen in Table 5). ${ }^{744} \mathrm{Pr}$ is calculated as equal to the ${ }^{144} \mathrm{Ce}$ result. The ${ }^{135} \mathrm{Cs}$ result assumes that all of mass 135 from the ICPMS result is ${ }^{135} \mathrm{Cs}$. The ${ }^{232} \mathrm{Th}$ result assumes that all of mass 232 from the ICPMS result is ${ }^{232} \mathrm{Th}$. Total gamma is calculated as the sum of the ${ }^{137} \mathrm{Cs},{ }^{134} \mathrm{Cs},{ }^{135} \mathrm{Cs},{ }^{60} \mathrm{Co},{ }^{94} \mathrm{Nb},{ }^{106} \mathrm{Ru},{ }^{125} \mathrm{Sb},{ }^{126} \mathrm{Sn},{ }^{144} \mathrm{Ce},{ }^{144} \mathrm{Pr},{ }^{154} \mathrm{Eu}$, 
${ }^{155} \mathrm{Eu}$, and ${ }^{226} \mathrm{Ra}$. The ${ }^{238} \mathrm{Pu},{ }^{239 / 40} \mathrm{Pu}$, and ${ }^{241} \mathrm{Pu}$ results are from radio-counting, while the other Pu results are from ICPMS. The ${ }^{239 / 40} \mathrm{Pu}$ value is not tainted by detection limits as the ICPMS ${ }^{240} \mathrm{Pu}$, although care must be taken into assuming a correct 239/240 isotopic breakdown.

Table 6. Radiological Results of Tank 21H Analyses for Macrobatch 7

\begin{tabular}{|c|c|c|c|}
\hline Analyte & Average Result & Analyte & Average Result \\
\hline${ }^{3} \mathrm{H}$ & $5.28 \mathrm{E}+02(14.1 \%)$ & ${ }^{155} \mathrm{Eu}$ & $<4.73 \mathrm{E}+01$ \\
\hline${ }^{14} \mathrm{C}$ & $7.40 \mathrm{E}+02(30.3 \%)$ & ${ }^{226} \mathrm{Ra}$ & $<6.71 \mathrm{E}+01$ \\
\hline${ }^{59} \mathrm{Ni}$ & $<2.03 \mathrm{E}+00$ & ${ }^{232} \mathrm{U}$ & $2.32 \mathrm{E}+00(26.0 \%)$ \\
\hline${ }^{63} \mathrm{Ni}$ & $<3.15 \mathrm{E}+01$ & ${ }^{233} \mathrm{U}$ & $<9.68 \mathrm{E}+01$ \\
\hline${ }^{60} \mathrm{Co}$ & $<1.88 \mathrm{E}+00$ & ${ }^{234} \mathrm{U}$ & $9.66 \mathrm{E}+01(18.8 \%)$ \\
\hline${ }^{90} \mathrm{Sr}$ & $2.61 \mathrm{E}+05(7.33 \%)$ & ${ }^{235} \mathrm{U}$ & $4.19 \mathrm{E}-01(0.00 \%)$ \\
\hline${ }^{90} \mathrm{Y}$ & $2.61 \mathrm{E}+05(7.33 \%)$ & ${ }^{236} \mathrm{U}$ & $1.09 \mathrm{E}+00(20.6 \%)$ \\
\hline${ }^{94} \mathrm{Nb}$ & $<1.03 \mathrm{E}+01$ & ${ }^{238} \mathrm{U}$ & $9.16 \mathrm{E}+00(1.82 \%)$ \\
\hline${ }^{99} \mathrm{Tc}$ & $1.67 \mathrm{E}+04(1.71 \%)$ & ${ }^{237} \mathrm{~Np}$ & $<7.05 \mathrm{E}+00$ \\
\hline${ }^{106} \mathrm{Ru}$ & $<1.41 \mathrm{E}+02$ & ${ }^{238} \mathrm{Pu}(\mathrm{unfiltered})$ & $1.15 \mathrm{E}+04(1.38 \%)$ \\
\hline${ }^{106} \mathrm{Rh}$ & $<1.41 \mathrm{E}+02$ & ${ }^{238} \mathrm{Pu}(\mathrm{filtered})$ & $1.20 \mathrm{E}+04(3.18 \%)$ \\
\hline${ }^{125} \mathrm{Sb}$ & $<1.07 \mathrm{E}+02$ & ${ }^{239} \mathrm{Pu}$ & $1.57 \mathrm{E}+03(20 \%)$ \\
\hline${ }^{125 \mathrm{~m}} \mathrm{Te}$ & $<1.07 \mathrm{E}+02$ & ${ }^{240} \mathrm{Pu}$ & $<2.28 \mathrm{E}+03$ \\
\hline${ }^{126} \mathrm{Sn}$ & $1.32 \mathrm{E}+02(9.88 \%)$ & ${ }^{239 / 40} \mathrm{Pu}$ & $6.62 \mathrm{E}+02(4.81 \%)$ \\
\hline${ }^{129} \mathrm{I}$ & $1.21 \mathrm{E}+01(6.86 \%)$ & ${ }^{241} \mathrm{Pu}$ & $2.21 \mathrm{E}+03(3.02 \%)$ \\
\hline${ }^{134} \mathrm{Cs}$ & $<4.07 \mathrm{E}+03$ & ${ }^{242} \mathrm{Pu}$ & $<3.82 \mathrm{E}+01$ \\
\hline${ }^{135} \mathrm{Cs}$ & $2.47 \mathrm{E}+02(12.9 \%)$ & ${ }^{244} \mathrm{Pu}$ & $<1.77 \mathrm{E}-01$ \\
\hline${ }^{137} \mathrm{Cs}$ & $4.61 \mathrm{E}+07(2.07 \%)$ & ${ }^{241} \mathrm{Am}$ & $<2.53 \mathrm{E}+00$ \\
\hline${ }^{137 m} \mathrm{Ba}$ & $4.37 \mathrm{E}+07(2.07 \%)$ & ${ }^{243} \mathrm{Am}$ & $<7.16 \mathrm{E}-01$ \\
\hline${ }^{144} \mathrm{Ce}$ & $<1.16 \mathrm{E}+02$ & ${ }^{244} \mathrm{Cm}$ & $2.34 \mathrm{E}+00(43.1 \%)$ \\
\hline${ }^{144} \mathrm{Pr}$ & $<1.16 \mathrm{E}+02$ & ${ }^{245} \mathrm{Cm}$ & $<1.87 \mathrm{E}+00$ \\
\hline${ }^{147} \mathrm{Pm}$ & $<2.71 \mathrm{E}+01$ & Total Alpha & $<1.01 \mathrm{E}+05$ \\
\hline${ }^{151} \mathrm{Sm}$ & $<1.23 \mathrm{E}+01$ & Total Beta & $9.18 \mathrm{E}+07(0.69 \%)$ \\
\hline${ }^{154} \mathrm{Eu}$ & $<7.11 \mathrm{E}+00$ & $T 0 t a l \mathrm{Gamma}$ & $4.61 \mathrm{E}+07$ \\
\hline
\end{tabular}

Shaded results are calculated values. Values in parentheses are the RSD unless only a single result, then the value is the analytical uncertainty. Values in italics are single results.

Results given in italics indicate that one of the sample results was either below detection or quantification limits, in which case the value in the parentheses is the analytical uncertainty. Only quantifiable measured values are reported when available. 


\subsection{Results of the MST Strike}

During the experiment, personnel collected samples from each of the two bottles at 0,4 , and 8 hours. For the sample at 0 hours, sampling occurred immediately prior to MST addition. Technicians filtered the samples using $0.45 \mu \mathrm{m}$ Versapor ${ }^{\mathrm{TM}}$ syringe filters, removed the samples from the cells for analysis, and analyzed for plutonium (PuTTA), ${ }^{90} \mathrm{Sr}$ (beta scintillation), and ${ }^{238} \mathrm{U}$ (ICPMS). ${ }^{237} \mathrm{~Np}$ and ${ }^{243} \mathrm{Am}$ were both observed to be below detection limits in the source material, and so these results are not reported. Additionally, the anion (IC Anions) and metal (ICPES) concentrations were tracked after the first scrub and first strip to better understand the chemistry occurring between these steps in the NGS, NGS-MCU blends, and MCU solvents. Samples were sent to Analytical Development (AD) with moderate dilution, and those dilutions are accounted for in the results section.

Compared to the MST test in Salt Batch $6{ }^{8}$ the current test delivered better Pu removal, but worse Sr removal. However, given the variability between the tests, these differences are not significant. Based on the data, the MST test results provide for adequate $\mathrm{Pu}$ and Sr removal for the salt batch.

\subsubsection{Plutonium Results}

Researchers analyzed the filtered samples for ${ }^{238} \mathrm{Pu}$. Table 7 shows the plutonium results while Figure 2 shows the graphical results for ${ }^{238} \mathrm{Pu}$. The ${ }^{238} \mathrm{Pu}$ data is more useful than the ${ }^{239 / 40} \mathrm{Pu}$ as the former is not limited by detection limit values. The values in parentheses in Table 7 are the analytical uncertainty associated with the measurement and does not include any contribution to uncertainty due to experimental and sampling methods.

Table 7. ${ }^{238} \mathrm{Pu}$ Concentrations in the MST Strike Filtrates

\begin{tabular}{|c|c|c|c|}
\hline \multirow{2}{*}{$\begin{array}{c}\text { Time } \\
\text { (hours) }\end{array}$} & \multicolumn{3}{|c|}{${ }^{238} \mathrm{Pu}(\mathrm{pCi} / \mathrm{mL})$} \\
\cline { 2 - 4 } & Experiment\#1 & Experiment\#2 & Control \\
\hline $0 *$ & $1.23 \mathrm{E}+04(5.56 \%)$ & $1.23 \mathrm{E}+04(5.56 \%)$ & $1.23 \mathrm{E}+04(5.56 \%)$ \\
\hline 4 & $3.62 \mathrm{E}+03(6.00 \%)$ & $4.16 \mathrm{E}+03(5.07 \%)$ & $1.26 \mathrm{E}+04(5.42 \%)$ \\
\hline 8 & $3.48 \mathrm{E}+03(5.64 \%)$ & $2.78 \mathrm{E}+03(4.96 \%)$ & $1.77 \mathrm{E}+04(9.34 \%)$ \\
\hline
\end{tabular}

$*$ The time $=0$ data are the same data point.

The elevated 8 hour control point is likely due to cross-contamination. 


\section{Figure 2. ${ }^{238} \mathrm{Pu}$ in Solution over Time for the MST Sorption Test}

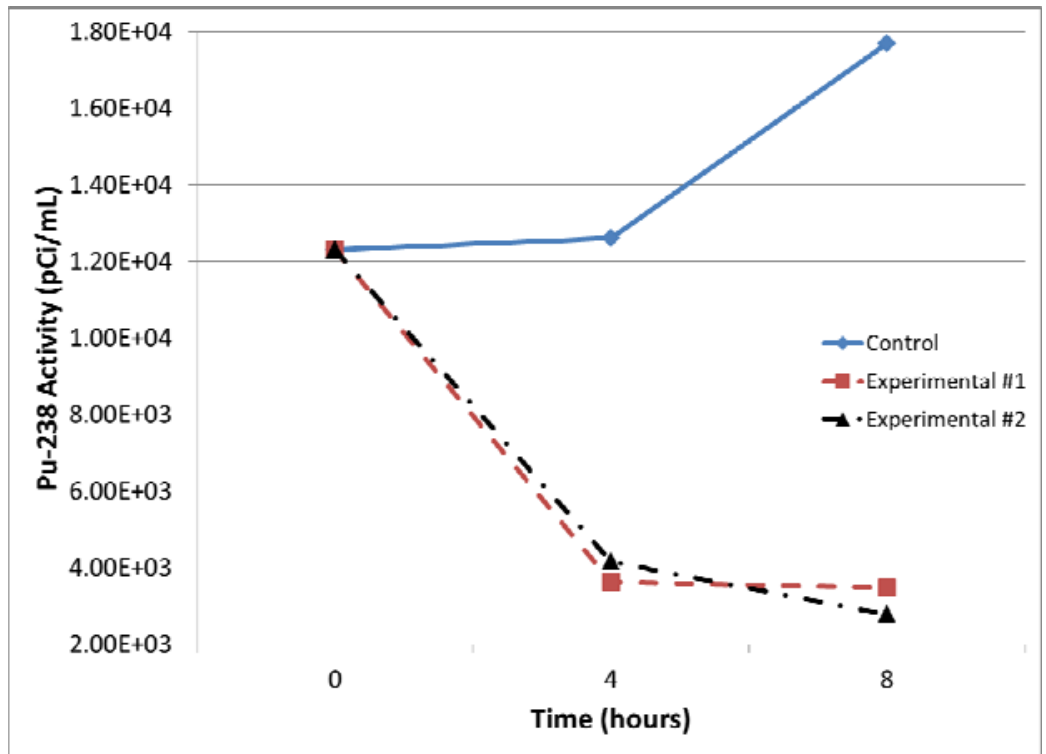

Table 8 lists the decontamination factors (DF) after the MST strike. ${ }^{\oplus}$

Table 8. ${ }^{238}$ Pu Decontamination Factors (DF) over Time

\begin{tabular}{|c|c|c|c|}
\hline \multirow{2}{*}{ Time (hours) } & \multicolumn{3}{|c|}{ DF } \\
\cline { 2 - 4 } & Experiment\#1 & Experiment\#2 & Control \\
\hline 4 & 3.40 & 2.96 & 0.98 \\
\hline 8 & 3.53 & 4.42 & 0.69 \\
\hline
\end{tabular}

While there is only a limited amount of data related to Pu removal under the experimental conditions, the results are within general expectations.

\subsubsection{Strontium Results}

Researchers analyzed the filtered samples for ${ }^{90} \mathrm{Sr}$. Table 9 shows the strontium results while Figure 3 shows the graphical results for ${ }^{90} \mathrm{Sr}$. The values in parentheses in Table 9 are the analytical uncertainty associated with the measurement and does not include any contribution to uncertainty due to experimental and sampling methods.

\footnotetext{
${ }^{\oplus} \mathrm{DF}$ is defined as the analyte concentration before decontamination (time $=0$ ), divided by the analyte concentration after decontamination.
} 
Table 9. ${ }^{90} \mathrm{Sr}$ Concentrations in the MST Strike Filtrates

\begin{tabular}{|c|c|c|c|}
\hline \multirow{2}{*}{$\begin{array}{c}\text { Time } \\
\text { (hours) }\end{array}$} & \multicolumn{3}{|c|}{${ }^{90} \mathrm{Sr}(\mathrm{pCi} / \mathrm{mL})$} \\
\cline { 2 - 4 } & Experiment\#1 & Experiment\#2 & Control \\
\hline $0^{*}$ & $2.23 \mathrm{E}+05(10.5 \%)$ & $2.23 \mathrm{E}+05(10.5 \%)$ & $2.23 \mathrm{E}+05(10.5 \%)$ \\
\hline 4 & $1.23 \mathrm{E}+04(10.7 \%)$ & $1.21 \mathrm{E}+04(10.6 \%)$ & $2.23 \mathrm{E}+05(10.7 \%)$ \\
\hline 8 & $1.49 \mathrm{E}+04(11.3 \%)$ & $1.27 \mathrm{E}+04(9.88 \%)$ & $2.23 \mathrm{E}+05(10.8 \%)$ \\
\hline
\end{tabular}

$*$ The time $=0$ data are the same data point.

Figure 3. ${ }^{90} \mathrm{Sr}$ in Solution over Time for the MST Sorption Test

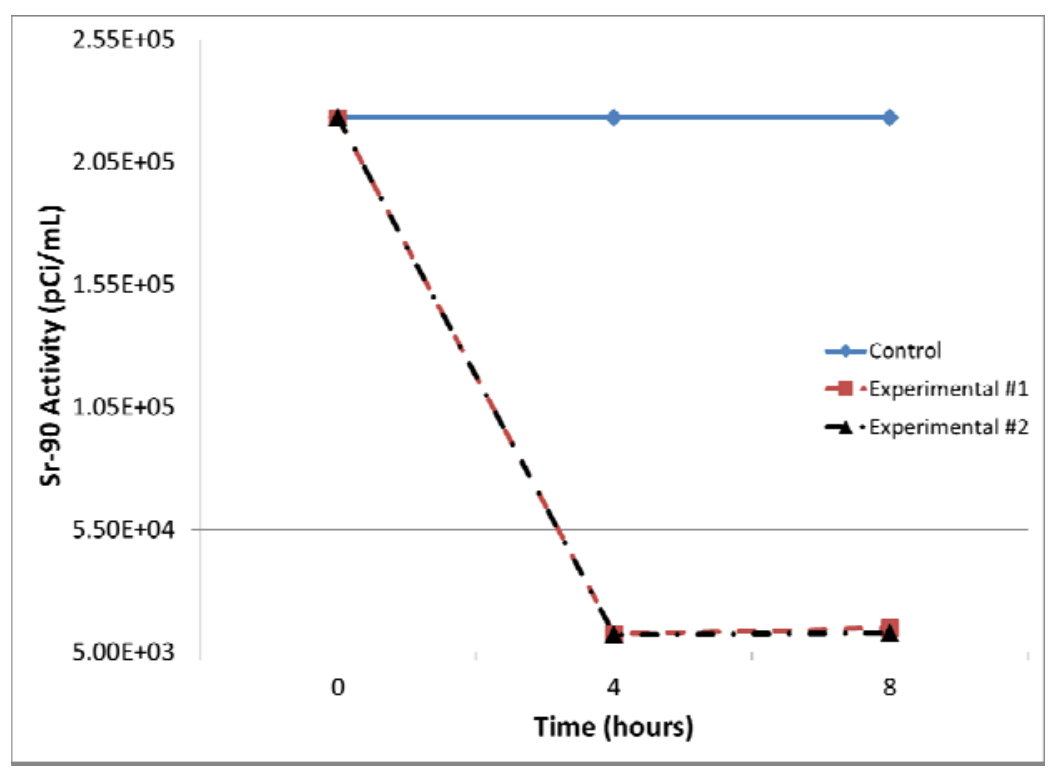

Table 10 lists the decontamination factors (DF) after the MST strike.

Table 10. ${ }^{90}$ Sr Decontamination Factors (DF) over Time

\begin{tabular}{|c|c|c|c|}
\hline \multirow{2}{*}{ Time (hours) } & \multicolumn{3}{|c|}{ DF } \\
\cline { 2 - 4 } & Experiment\#1 & Experiment\#2 & Control \\
\hline 4 & 18.2 & 18.5 & 1.00 \\
\hline 8 & 15.0 & 17.5 & 1.00 \\
\hline
\end{tabular}

While there is only a limited amount of data related to Sr removal under the experimental conditions, the results are within general expectations. 


\subsubsection{Uranium Results}

Researchers analyzed the filtered samples for ${ }^{238} \mathrm{U}$. Table 11 shows the uranium results while Figure 4 shows the graphical results for ${ }^{238} \mathrm{U}$. The values in parentheses in Table 11 are the analytical uncertainty associated with the measurement and does not include any contribution to uncertainty due to experimental and sampling methods.

\section{Table 11. ${ }^{238} \mathrm{U}$ Concentrations in the MST Strike Filtrates}

\begin{tabular}{|c|c|c|c|}
\hline \multirow{2}{*}{$\begin{array}{c}\text { Time } \\
\text { (hours) }\end{array}$} & \multicolumn{3}{|c|}{${ }^{238} \mathrm{U}(\mathrm{pCi} / \mathrm{mL})$} \\
\cline { 2 - 4 } & Experiment\#1 & Experiment\#2 & Control \\
\hline $0^{*}$ & $9.54 \mathrm{E}+00(20 \%)$ & $9.54 \mathrm{E}+00(20 \%)$ & $9.54 \mathrm{E}+00(20 \%)$ \\
\hline 4 & $9.21 \mathrm{E}+00(20 \%)$ & $8.97 \mathrm{E}+00(20 \%)$ & $9.11 \mathrm{E}+00(20 \%)$ \\
\hline 8 & $9.11 \mathrm{E}+00(20 \%)$ & $9.07 \mathrm{E}+00(20 \%)$ & $9.54 \mathrm{E}+00(20 \%)$ \\
\hline
\end{tabular}

$*$ The time $=0$ data are the same data point.

Figure 4. ${ }^{238} \mathrm{U}$ in Solution over Time for the MST Sorption Test

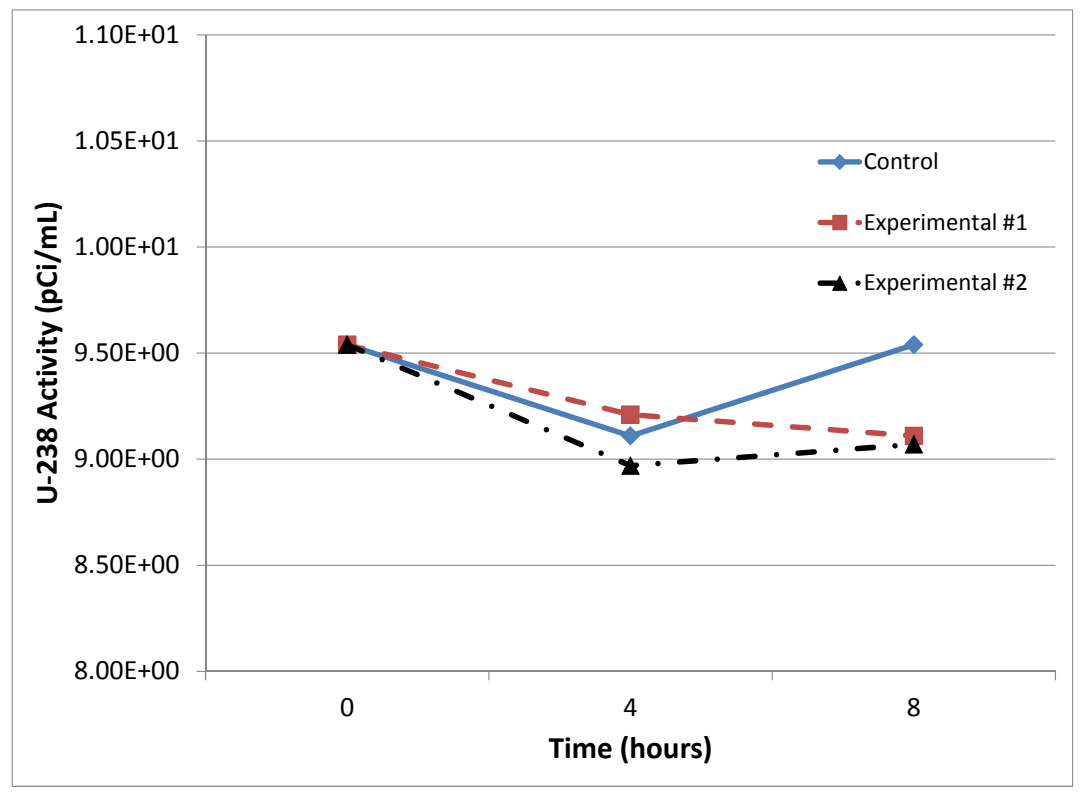

The small dip in the U graph is within the analytical uncertainty of the measurement and is not indicative of a drop in performance.

Table 12 lists the DF after the MST strike. 
Table 12. ${ }^{238}$ U Decontamination Factors (DF) Over Time

\begin{tabular}{|c|c|c|c|}
\hline \multirow{2}{*}{ Time (hours) } & \multicolumn{3}{|c|}{ DF } \\
\cline { 2 - 4 } & Experiment\#1 & Experiment\#2 & Control \\
\hline 4 & 1.00 & 1.03 & 1.02 \\
\hline 8 & 1.01 & 1.02 & 1.00 \\
\hline
\end{tabular}

Given the small concentration of MST used and the small effect that MST has on uranium, the uranium removal results are within expectations.

\subsubsection{Neptunium and Americium Results}

There was insufficient ${ }^{237} \mathrm{~Np}$ and ${ }^{243} \mathrm{Am}$ in the feed solution to determine any decontamination effects of MST.

\subsection{Results of the ESS Test}

For the ESS Tests, filtrate from the MST Sorption Test was used. Table 13 shows the results from the ESS tests, corrected to the normal process operating temperatures (i.e., $23{ }^{\circ} \mathrm{C}$ for extraction and $33{ }^{\circ} \mathrm{C}$ for scrubbing and stripping). For the MCU solvent test, the temperature correction factors for the BOBCalix solvent formulation were used. For the other three tests, the temperature correction factors for the NGS solvent were used (see Appendix A).

The temperature in the shielded cells during the ESS test ranged from $22.3^{\circ} \mathrm{C}$ to $26.0^{\circ} \mathrm{C}$ with an average temperature of $24.8^{\circ} \mathrm{C}$. As a comparison, the results from the previous macrobatch qualification ESS test (using the same solvent) are displayed. ${ }^{6}$

Table 13. Cesium Distribution Ratios $\left(D_{(C)}\right)$ for the ESS Tests

\begin{tabular}{|c|c|c|c|c|c|c|}
\hline Material & Extraction & Scrub\#1 & Scrub\#2 & Strip\#1 & Strip\#2 & Strip\#3 \\
\hline $\begin{array}{c}\text { Acceptable Range } \\
\text { for BOBCalix Solvent }\end{array}$ & $>8$ & $>0.6,<2$ & $>0.6,<2$ & $<0.2$ & $<0.16$ & $<0.16$ \\
\hline $\begin{array}{c}\text { S2-D1-YES BOB-T- } \\
\begin{array}{c}\text { WI, ISDP 6 (previous } \\
\text { test) }\end{array}\end{array}$ & 9.14 & 2.72 & 0.800 & 0.0396 & 0.0184 & 0.0247 \\
\hline MCU Solvent & 15.96 & 1.25 & 0.662 & 0.0365 & 0.0220 & 0.0204 \\
\hline Cold Blend (NGS) & 57.1 & 4.45 & 1.74 & 0.0237 & 0.00053 & 0.00741 \\
\hline Hot Blend (NGS) & 58.6 & 2.32 & 2.58 & 0.00057 & 0.00257 & 0.0111 \\
\hline NGS & 65.6 & 4.05 & 1.82 & 0.00020 & 0.00103 & 0.00995 \\
\hline
\end{tabular}

\footnotetext{
${ }^{\Upsilon}$ This batch of solvent was originally prepared with no extractant as S2-NOBOB-T-WI (see WSRC-NB-2005-00060).
} The extractant was added later (see WSRC-NB-2007-00054). 
The four current tests show the expected behaviors, with good overall performance. For the MCU solvent test, the extraction, scrub and strip values are all comparable to a range of previous test results. For the other three tests, other than some differences in the strip results, the results were very similar. For example, strip\#1 for the Cold Blend is somewhat higher than other strip\#1 results for the NGS type experiments. This may be related to the elevated levels of sodium, nitrite and nitrite in the strip\#1 solution (see Table 17), although the precise reason for this is unclear. On the other hand, the strip\#2 result for the Cold Blend test is the best of all three NGS type tests. Despite the variations between the three NGS type strip results, all three NGS type tests give acceptable results.

From the bulk chemistry of the solution, an extraction $\mathrm{D}_{(\mathrm{Cs})}$ of 13.2 is predicted for the MCU solvent. ${ }^{9}$ The bulk chemical characteristics of this batch are roughly similar to that of Salt batch $6 .^{\notin}$ The largest chemical differences that could affect the cesium distributions values are the potassium and nitrate. Salt Batch 6 had a higher potassium concentration (460 vs $288 \mathrm{mg} / \mathrm{L}$ ) and a lower nitrate concentration (138500 vs. 148000 $\mathrm{mg} / \mathrm{L})$.

At this time we do not have a simple model to predict the extraction behavior of any solvent containing NGS or a blend containing NGS.

\subsubsection{Strip Effluent and DSS Results}

During, and at the end of the ESS test, the gamma activity in the strip effluent and the decontaminated salt solution (DSS) for a single extraction was measured. The results are shown in Table 14. The pH measurements of the same are shown in Table 15.

Table 14. Strip Effluent and DSS Results

\begin{tabular}{|c|c|c|c|c|}
\hline Sample & \multicolumn{4}{|c|}{$\mathbf{1 3 7}$ Cs activity (pCi/mL) } \\
\hline & MCU & $\begin{array}{c}\text { Cold } \\
\text { Blend }\end{array}$ & Hot Blend & NGS \\
\hline Strip Effluent \#1 & $2.01 \mathrm{E}+08$ & $3.91 \mathrm{E}+08$ & $4.77 \mathrm{E}+08$ & $5.00 \mathrm{E}+08$ \\
\hline Strip Effluent \#2 & $6.85 \mathrm{E}+07$ & $9.14 \mathrm{E}+07$ & $2.86 \mathrm{E}+06$ & $2.03 \mathrm{E}+06$ \\
\hline Strip Effluent \#3 & $1.58 \mathrm{E}+07$ & $1.30 \mathrm{E}+06$ & $2.62 \mathrm{E}+05$ & $1.09 \mathrm{E}+05$ \\
\hline DSS & $6.71 \mathrm{E}+06$ & $3.22 \mathrm{E}+06$ & $3.12 \mathrm{E}+06$ & $2.68 \mathrm{E}+06$ \\
\hline
\end{tabular}

The analytical uncertainty on the ${ }^{137}$ Cs activity is $5 \%$.

${ }^{\notin}$ As a point of comparison, Salt Batch 6 had a predicted extraction distribution value of 13.7. 
Table 15. Strip Effluent and DSS Results

\begin{tabular}{|c|c|c|c|c|}
\hline Sample & \multicolumn{4}{|c|}{ pH } \\
\hline & MCU & Cold Blend & Hot Blend & NGS \\
\hline Strip Effluent \#1 & 4 & 8 & 7 & 8 \\
\hline Strip Effluent \#2 & 4 & 7 & 7 & 7 \\
\hline Strip Effluent \#3 & 4 & 7 & 8 & 8 \\
\hline DSS & 14 & 14 & 14 & 14 \\
\hline
\end{tabular}

The analytical uncertainty is $\pm 1 \mathrm{pH}$ unit for the $\mathrm{pH}$ measurement. The differences in the strip $\mathrm{pH}$ values between the MCU solvent and the other three tests are due to the different scrub and strip solutions.

\subsubsection{Anion and Metal Results}

Researchers analyzed the aqueous portion of the first scrub and first strip samples using Ion chromatography for anions and inductively coupled plasma electron spectroscopy for metal concentrations. The intent lies in investigating any patterns or trends that appear in each test either in the presence or absence of an ion or metal that can be related to the efficacy of the test. The scrub\#1 results are shown in Table 16 and the strip\#1 results in Table 17.

Table 16. Anion and Metal Results for Scrub\#1 Samples (mg/L)

\begin{tabular}{|c|c|c|c|c|}
\hline Analyte & MCU Scrub \#1 & $\begin{array}{c}\text { Cold Blend } \\
\text { Scrub \#1 }\end{array}$ & $\begin{array}{c}\text { Hot Blend } \\
\text { Scrub \#1 }\end{array}$ & NGS Scrub \#1 \\
\hline Nitrite & 61 & 258 & 239 & 218 \\
\hline Nitrate & 2090 & 1380 & 1310 & 1260 \\
\hline Sulfate & $<10$ & 37 & 35 & 26 \\
\hline $\mathrm{Al}$ & 0.409 & 17.9 & 19.1 & 17.2 \\
\hline $\mathrm{B}$ & $<0.08$ & 0.292 & 0.236 & $<0.159$ \\
\hline $\mathrm{Ca}$ & 0.174 & 0.336 & 0.28 & 0.317 \\
\hline $\mathrm{K}$ & 173 & 398 & 319 & 470 \\
\hline $\mathrm{Li}$ & 0.132 & 0.205 & 0.24 & 0.146 \\
\hline $\mathrm{Mg}$ & 0.0234 & 0.0174 & 0.0288 & $<0.008$ \\
\hline $\mathrm{Na}$ & 723 & 1940 & 1770 & 2290 \\
\hline $\mathrm{Si}$ & 8.59 & 11.6 & 14.8 & 10.2 \\
\hline
\end{tabular}

The analytical uncertainty is $10 \%$.

There are some noticeable differences between the MCU solvent results $(0.05 \mathrm{M}$ nitric acid scrub) and the other three tests $(0.025 \mathrm{M} \mathrm{NaOH}$ scrub). Nitrite is much lower in the 
MCU solvent test. Nitrate in the MCU is elevated, undoubtedly due to the nitric acid scrub used in that test, although one would predict a nitrate concentration of $3100 \mathrm{mg} / \mathrm{L}$ (0.05 M).

Aluminum and sulfate are much higher in the non-MCU tests, although the reason for this is not known.

Potassium and sodium are elevated in the non-MCU tests, which must be due to the higher concentration of extractant, which is known to uptake these elements, and therefore, these results are not surprising.

Table 17. Anion and Metal Results for Strip\#1 Samples (mg/L)

\begin{tabular}{|c|c|c|c|c|}
\hline Analyte & MCU Strip \#1 & $\begin{array}{c}\text { Cold Blend } \\
\text { Strip \#1 }\end{array}$ & $\begin{array}{c}\text { Hot Blend } \\
\text { Strip \#1 }\end{array}$ & NGS Strip \#1 \\
\hline Nitrite & $<10$ & 100 & 3 & 1 \\
\hline Nitrate & 173 & 285 & 19 & $<10$ \\
\hline Sulfate & $<10$ & 28 & $<10$ & $<10$ \\
\hline $\mathrm{Al}$ & $<0.315$ & 3.85 & $<1.23$ & $<0.315$ \\
\hline $\mathrm{B}$ & $<0.08$ & 105 & 103 & 104 \\
\hline $\mathrm{Ca}$ & 0.298 & 0.34 & 0.54 & 0.178 \\
\hline $\mathrm{K}$ & $<0.952$ & $<4.16$ & $<10.4$ & 2.57 \\
\hline $\mathrm{Li}$ & $<0.028$ & $<0.076$ & $<0.19$ & 0.052 \\
\hline $\mathrm{Mg}$ & 0.03 & 0.0444 & 0.101 & 0.0506 \\
\hline $\mathrm{Na}$ & 4.51 & 477 & 36.1 & 17.4 \\
\hline $\mathrm{Si}$ & 3.16 & 4.28 & 3.15 & 4.45 \\
\hline
\end{tabular}

The analytical uncertainty is $10 \%$.

Other than the boron values (from the strip boric acid), there are no obvious trends in the strip acid data. The sodium value in the cold blend is higher than expected, given the other results, but the reason is not known at this time.

\subsection{Conclusions}

Results of the analyses of the Tank $21 \mathrm{H}$ samples from this report in conjunction with the findings of the previous report, ${ }^{1}$ indicates that the material does not display any unusual characteristics nor pose any concerns for processing or the batching strategy.

This report also covers the MST sorption and ESS results for the ISDP Salt Batch 7 feed sample. The following observations are made from the work. 
- A demonstration of the monosodium titanate $(0.2 \mathrm{~g} / \mathrm{L})$ removal of strontium and actinides provided acceptable 4 hour average decontamination factor for $\mathrm{Pu}$ and $\mathrm{Sr}$ of 3.22 and 18.4, respectively.

- A set of four demonstrations of cesium extraction, scrubbing and stripping cesium mass transfer - intended to mimic any possible solvent system - yielded expected behavior.

While no outstanding issues were noted, the presence of solids in the samples should be investigated in future work. It is possible that the solids may represent a potential reservoir of material (such as potassium) that could have an impact on MCU performance if they were to dissolve back into the feed solution.

In addition, SRNL recommends that a model for predicting extraction behavior for cesium removal for the blended solvent and NGS be developed. 


\section{Appendix A. Temperature Correction Factors for the ESS Tests}

The actual MCU facility uses active temperature control to keep the extraction and scrub steps to $23{ }^{\circ} \mathrm{C}$, and the strip steps to $33{ }^{\circ} \mathrm{C}$. However, the ESS tests do not have active temperature control. During each step of an ESS test, the calculated distribution values must be corrected for temperature. The general formula for temperature correction is as follows:

correction factor $=\operatorname{EXP}((\mathbf{C O E F} / 0.0083144) *((1 /$ TEMP $)-(1 /($ STEP $))))$

where "COEF" is the particular temperature coefficient for the step in question, the "TEMP" is the ambient temperature, in Kelvin, and "STEP" is 296.15 for extraction and scrub and 306.15 for strip steps. There is one set of coefficients for the MCU solvent, and one set of coefficients for use in NGS type solvents with MaxCalix (NGS, cold blend, hot blend).

Table 18 lists the temperature coefficients for each step in an ESS test. The coefficients for the NGS solvent are derived from the van't Hoff formalism in equation 1 of the applicable reference.

Table 18. Temperature Coefficients

\begin{tabular}{|c|c|c|}
\hline Step & MCU $^{\mathbf{1 0}}$ & NGS $^{\mathbf{1 1}}$ \\
\hline Extraction & -47.95 & -90.12 \\
\hline Scrub\#1 & -86.82 & -115.5 \\
\hline Scrub\#2 & -74.24 & -91.40 \\
\hline Strip\#1 & -79.36 & -80.18 \\
\hline Strip\#2 & -82.94 & -143.4 \\
\hline Strip\#3 & -82.49 & -65.63 \\
\hline
\end{tabular}




\subsection{References}

${ }^{1}$ T. B. Peters, A. L. Washington II, "Results of Initial Analyses of the Macrobatch 7 Tank 21H Qualification Samples”, SRNL-STI-2013-00346, June 2013.

${ }^{2}$ S. E. Campbell, and J. W. Ray, “Technical Task Request - Qualification of ISDP Salt Batch 7”, HLW-DWPF-TTR-2013-0043, Rev. 1, June 20, 2013.

${ }^{3}$ T. B. Peters and A. L. Washington, II. "Task Technical and Quality Assurance Plan for ISDP Salt Batch 7 Sample Qualification”, SRNL-RP-2013-00283, Rev. 0, May, 2013.

${ }^{4}$ T. B. Peters, “ISDP7”, SRNL-NB-2013-00040, June 11, 2013.

${ }^{5}$ S. E. Campbell, “Solids Settling in Tank 21H Sample”, SRR-LWE-2013-00105, May 29, 2013.

${ }^{6}$ A. L. Washington II, T. B. Peters, S. D. Fink, "Interim Salt Disposition Program Macrobatch 6 Tank 21H Qualification Monosodium Titanate and Cesium Mass Transfer Tests”, SRNL-STI-2013-00034, February 2013.

${ }^{7}$ http://www.nndc.bnl.gov, E. Browne, J. K. Tuli Citation: Nuclear Data Sheets 108, $2173(2007)$

${ }^{8}$ T. B. Peters, S. D. Fink, "Results of Initial Analyses of the Macrobatch 6 Tank 21H Qualification Samples”, SRNL-STI-2012-00685, November 2012.

${ }^{9}$ K. Adu-Wusu, D. D. Walker, T. B. Edwards, "Waste and Solvent Composition Limits for Modular Caustic-Side Solvent Extraction Unit (MCU)”, WSRC-TR-2005-00258, May 26, 2005.

${ }^{10}$ L. H. Delmau, J. F. Birdwell Jr., P. V. Bonnesen, L. J. Foote, T. J. Haverlocke, L. N. Klatt, D. D. Lee, R. A. Leonard, T. G. Levitskaia, M. P. Maskarinec, B. A. Moyer, F. V. Sloop Jr., B. A. Tomkins, "Caustic-Side Solvent Extraction: Chemical and Physical Properties of the Optimized Solvent”, ORNL/TM-2002/190, October 2002.

${ }^{11}$ N. J. Williams, B. A. Moyer, "Temperature Dependence of the Next Generation Caustic Side Solvent Extraction (NG-CSSX) Process Solvent", ORNL-LTRNGCSSX-012, August 5, 2011. 